\title{
Dynamics of top-down factors with relation to ecological attributes of an endangered species Commiphora wightii
}

\author{
R. N. Kulloli* , Manish Mathur and Suresh Kumar \\ Central Arid Zone Research Institute, Jodhpur-342003 (Rajasthan), INDIA \\ *Corresponding author. Email: r.kulloli@gmail.com \\ Received: September 11, 2015; Revised received: July 18, 2016; Accepted: July 12, 2016
}

\begin{abstract}
Present study was aimed to explore the influence of top down factors on ecological attributes of Commiphora wightii collected from seven districts of arid and semi arid parts of the Rajasthan. Ecological variables in respect of 46 accessions of this species were quantified. To assess the explanatory factors governing quantified ecological variables, soil samples were collected to analyze soil texture, soil $\mathrm{EC}, \mathrm{pH}$, available potassium, available phosphorus and total soil nitrogen. Results showed that there was a specific relationship between soil variables and occurence of $C$. wightii. The mid ranges of potassium $(200-300 \mathrm{~kg} / \mathrm{ha})$ emerged as favourable to have better density and health of $C$. wightii: This is the first report on regulatory role of potassium on distribution and occurrence of $C$. wightii.
\end{abstract}

Keywords: Commiphora wightii, Distribution, Population, Principal component analysis, Soil variables

\section{INTRODUCTION}

It is largely agreed that differences in the distribution and abundance of plant species in any environment are an indication of the variation in soil properties (Graham et al., 2005; Engler and Guisan, 2009). Conversely, a knowledge of soil properties across sites of occurrence also helps in deciding package of practices for reintroduction of species like $C$. wightii which is considered threatened now (Kumar and Purohit, 2015). In previous studies soil physico chemical parameters related to plant communities in the Indian desert were studied by Kumar and Shankar, 1988; Kumar and Shankar, 1982; Kumar, 1996 and Singh et al., 2012. These studies identified varying soil proprieties like organic matter, clay, silt and salinity which influence the distribution or zonation of vegetation; as well as tree size, vegetation cover, tree density and proportion of mesophanerophytes as vegetation components that influenced soil nutrients. Distribution of individual species on the basis of soil physicochemical parameters has also been studied in respect of Pedalium murex and Peganum harmala (Chauhan, 2004). Mathur (2012) also carried out similar studies in Corchorus depressus, Blepharis sindica and Tribulus terrestris. In a recent study, Lal (2013) correlated soil texture, moisture content, $\mathrm{pH}, \mathrm{EC}, \mathrm{OC}$, available phosphorus and nitrogen in soil with the $C$. wightii presence only at four sites, Kailana hill, Machia Park Jodhpur; Akal fossil park , Jaisalmer and Kiradu temple in Barmer which is inadequate. Hence the present study was conducted to identify the soil factors viz. soil texture, soil EC, $\mathrm{pH}$, available potassium, available phosphorus and total soil nitrogen governing population dynamics of C. wightii across various rainfall zones of the habitats of the Indian arid and semi-arid region.

\section{MATERIALS AND METHODS}

Study area : The study was carried out in Rajasthan state of India. We assessed guggal (C. wightii) from the year 2009 to 2012 in 35 expeditions in twenty districts of Rajasthan and located guggul in 11 districts (Table1). Of this, soil samples were collected from its sites of occurrence in seven districts (Jaisalmer, Barmer, Jalore, Pali, Jodhpur, Ajmer and Rajsamand (Fig.1).

Field sampling : The presence of $C$. wightii was recorded at 46 different sites located in 7 different districts. Ecological sampling was carried out through quadrate $(10 \times 10 \mathrm{~m})$ method (Ludwig and Reynolds, 1988). Community variables like diversity (Shannon and Weaver index, evenness) and relative importance value of $C$. wightii were quantified by following standard methodologies (Ludwig and Reynolds, 1988).

Soil analysis : Soil samples were collected upto $30 \mathrm{~cm}$ depth. Sieved soil samples were used for analysis of physical and chemical parameters. The water- soil suspension (5:1) was used to measure EC (Systronic Conductivity Meter-304) and $\mathrm{pH}$ (Systronic Digital $\mathrm{pH}$ Meter-802) at room temperature. Organic carbon was estimated by modified Walkley and Black's method (Jackson, 1973). Available potassium was estimated following Jackson (1973) method. Total soil nitrogen was estimated by alkaline permanganate method (Subbiah and Asija, 1965). Available phosphorus estimation was based on the development of molybdenum blue colour as described by Allen et al. (1976). 
Principal component analysis and synthesis of data: Principal component analysis (PCA) was employed as data reduction technique in which dominance of $C$. wightii (RIV) in plant community was plotted with soil and some community parameters. These factors included, organic carbon, nitrogen, phosphorus, $\mathrm{pH}$, electrical conductivity, Relative Importance Value (RIV) of C. wightii, Shannon and Weaver Index (H') and evenness. The interpretation of the PCA diagram was carried out as follows: when two variables are far from the center, then if they are: close to each other, they are significantly positively correlated ( $\mathrm{r}$ close to 1 ); if they are orthogonal, they are not correlated ( $r$ close to 0); if they are on opposite side of the center, then they are significantly negatively correlated ( $r$ close to -1). Squared cosines were used to link the variable with the corresponding axis and the greater the squared cosine, the greater the link with the corresponding axis. However, in order to determine basic soil, diversity (vegetation) and plant metabolites variables sustaining these interrelationships, the concept of component defining variables (CDV) which stipulates the selection and subsequent naming of variables with the highest component loading (correlation coefficient) as variables that provide the best relationships (Iwara et al., 2011; Mathur, 2012) was employed.

\section{RESULTS AND DISCUSSION}

Physical and chemical properties of soil : Physical and chemical parameters of soil of sites of occurrence of $C$. wightii are shown in Tables 2 and 3. Of the seven districts of occurrence of $C$. wightii, five had predominantly coarse (20-45\%) and gravelly soil texture (Table 2). In two districts it has less of coarse particles i.e. Jaisalmer and Jodhpur (4.16- 6.68\%). The $\mathrm{pH}$ of the soil ranged between 7.24 to 7.58 in areas receiving high rainfall $(>500 \mathrm{~mm}$ ) while it was 8.13 to 8.47 in areas receiving low rainfall $(200-300 \mathrm{~mm})$ in the districts of Jaisalmer, Barmer and Jodhpur (Table 2). It also shows that soils having neutral reaction, i.e. neither acidity nor sodicity/salinity are preferred by it. This is also evident by low electrical conductivity at all the sites and the highest being $0.66 \mathrm{ds} / \mathrm{m}^{2}$ at Rajsamand. Same trend was found in case of \% organic carbon. Mean potassium was ranged between 254.24 to $472 \mathrm{~kg} / \mathrm{ha}$ (Table 3). Maximum potassium was found in Barmer district (472 kg/ha) and minimum in Jodhpur district $(238.94 \mathrm{~kg} / \mathrm{ha})$ (Table 3). Sites of Jodhpur district showed lowest phosphorus content $(5.6 \mathrm{~kg} / \mathrm{ha})$ while highest was in Pali $(26.88 \mathrm{~kg} / \mathrm{ha})$ followed by Barmer $(26.04 \mathrm{~kg} / \mathrm{ha})$. Nitrogen content was low in sandy soil sites i.e. in Barmer and Jaisalmer $(9.79,9.88 \mathrm{~kg} / \mathrm{ha})$, while those in high rainfall and hilly region had more of $\mathrm{N}$ (Table 3 ). Maximum nitrogen was in sites of Rajsamand district (31.41 kg/ha).

District wise summary of dominance, evenness and diversity of $\boldsymbol{C}$. wightii: The mean RIV of $C$. wightii ranged from 9.32-17.39 (Table 4), though at protected sites its RIV was as high as 35 under protection e.g. at Devikot Mataji Temple, Jaisalmer and Kukda in Rajsamand. Species diversity as indicated by Shannon and Weavar index varied from $1.65-1.99$ for both protected and unprotected sites. This indicated that the diversity of sites having $C$. wightii was similar across habitats in various districts irrespective of its status of protection though compositionally the species at protected and unprotected sites were different. This also was the conclusion reached in an earlier study of $C$. wightii in Jamnagar, Gujarat (Kumar and Mathur, 2014). Evenness of vegetation varied from $0.86-0.99$ which only showed that dominance was more evenly distributed among different species at the sites of its occurrence (Table 4).

PCA result on soil parameters : PCA was performed on data of soil samples from seven (7) districts in order to identify critical soil factors that control distribution and population of $C$. wightii. In Jodhpur district there were only three sites of soil collection which had created bias due to which soil data of Jodhpur was omitted from PCA. Component loadings (correlation coefficients) and the variances (eigenvalues) for the various soil parameters were computed. As shown in Tables 5 and 6 , the first axis of PCA is the most important to explain variance across all the soil parameters. The percentage of eigenvalue for the first two components is $>50$ throughout six districts. District wise results are given below.

Ajmer district : Out of 10 different variables, seven variables were significant (Table 5). Soil properties like EC (0.89), $\mathrm{K} \mathrm{kg} / \mathrm{ha}$ (0.89), P kg/ha (0.74), $\mathrm{N} \mathrm{kg/ha}$ (- 0.72$)$ were related with $F 1$ axes with 3.36 eigenvalue

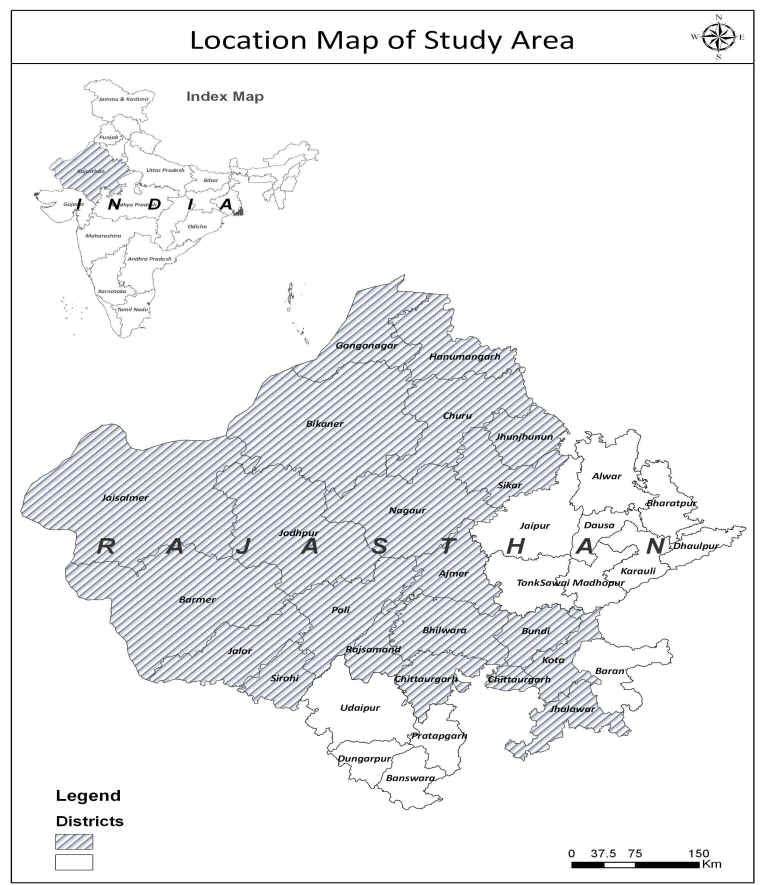

Fig 1. Study area of Guggal (C. wightii) in Rajasthan. 

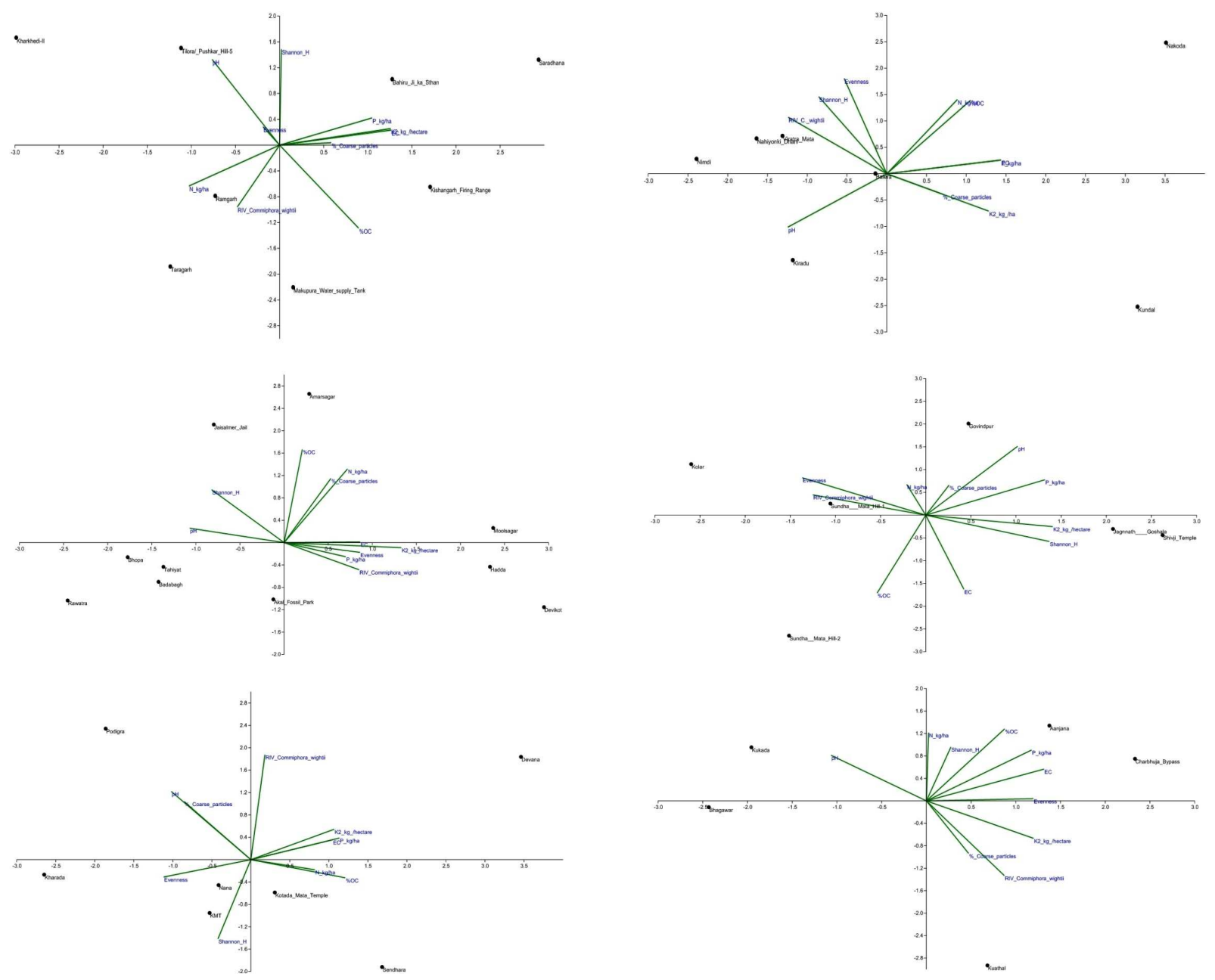

Fig. 2 a- f. PCA-ordination diagram of soil properties (physical and chemical) and community dynamics of C. wightii in different districts.

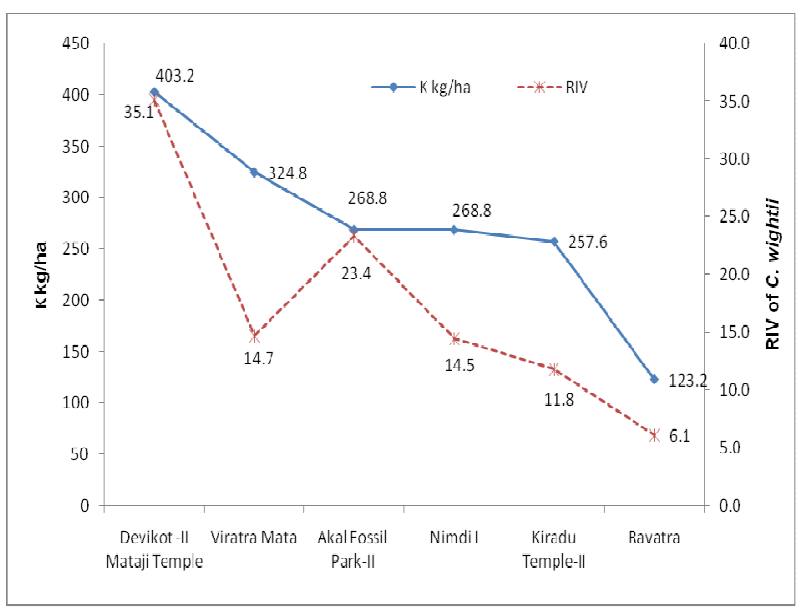

Fig. 3. Effect of soil potassium on RIV of C.wightii.

loading and $36.31 \%$ total variance in soil data set (Table 5). However pH (0.77), per cent OC (-0.75) and Shannon $\mathrm{H}$ (0.86) were plotted on component F2 where it accounted for 2.47 eigenvalue loading and

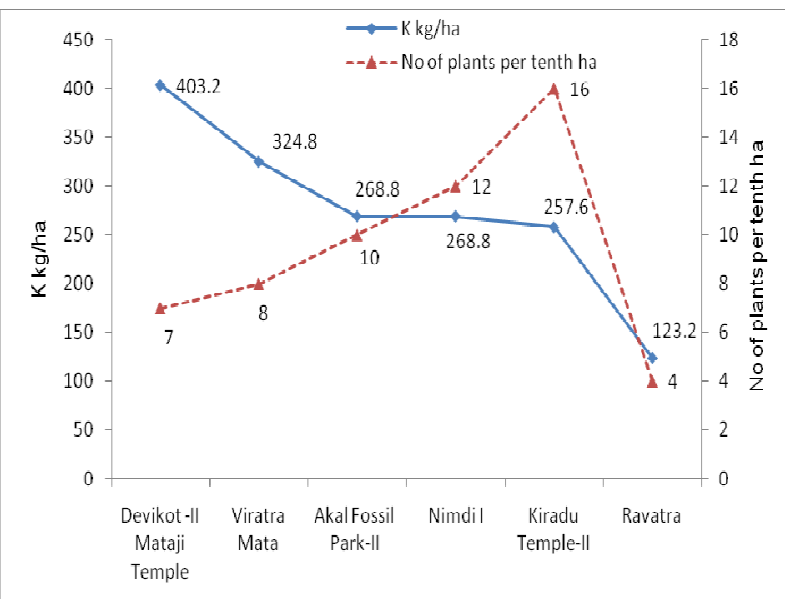

Fig. 4. Effect of soil potassium on number of plants per tenth ha.

24.68\% variance. Component F3 and component F4 had one soil parameters each and these axes accounted for $15.03 \%$ and $12.85 \%$ total explanation of community dynamics and soil data (Fig. 2a). Five variables 
R. N. Kulloli et al. / J. Appl. \& Nat. Sci. 8 (3): 1556 - 1564 (2016)

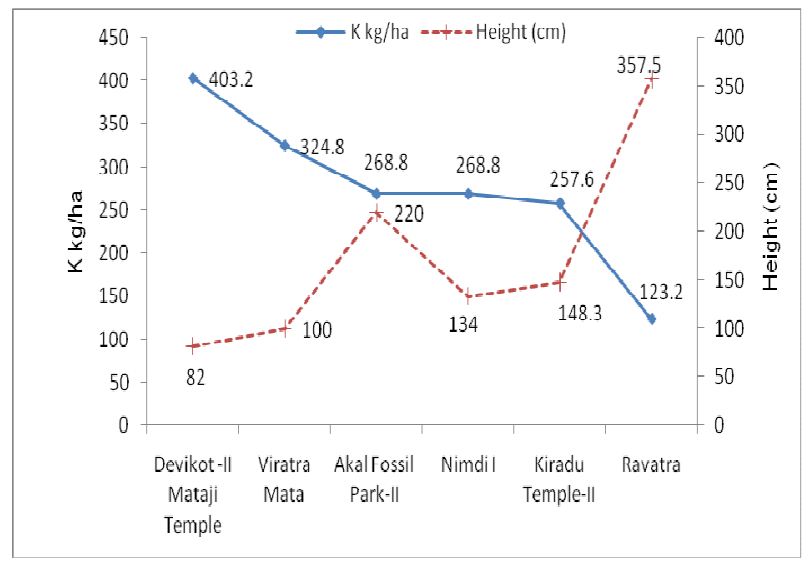

Fig. 5. Effect of soil potassium on height of C. wightii.

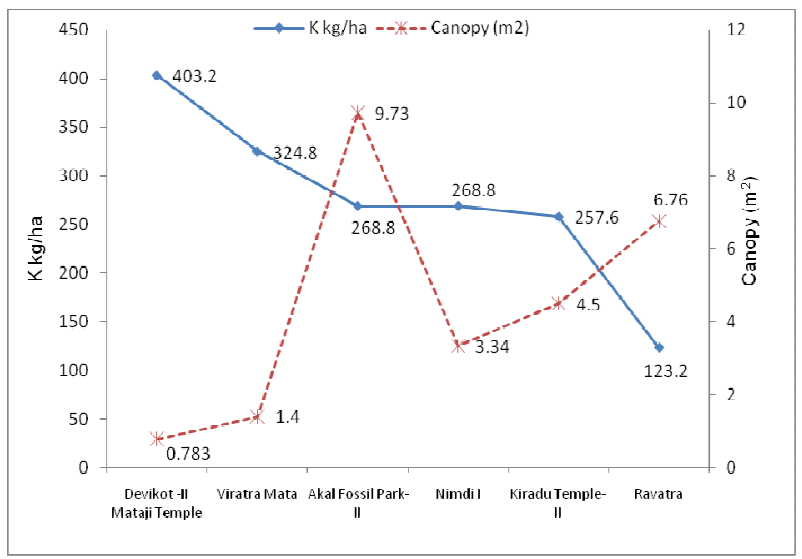

Fig. 6. Effect of soil potassium on canopy of C. wightii.

Table 1. Guggul (C. wightii) collection sites in study area.

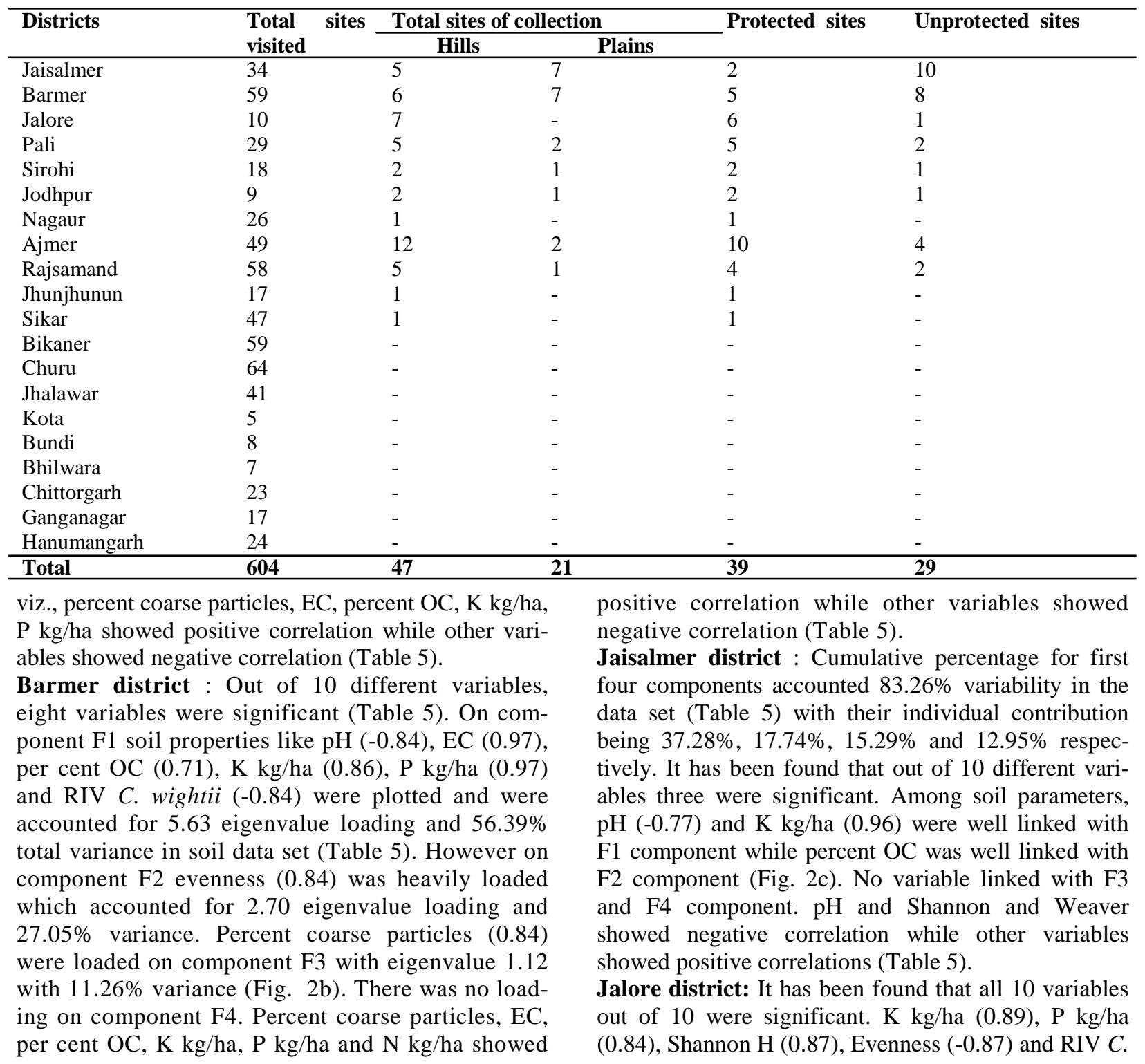




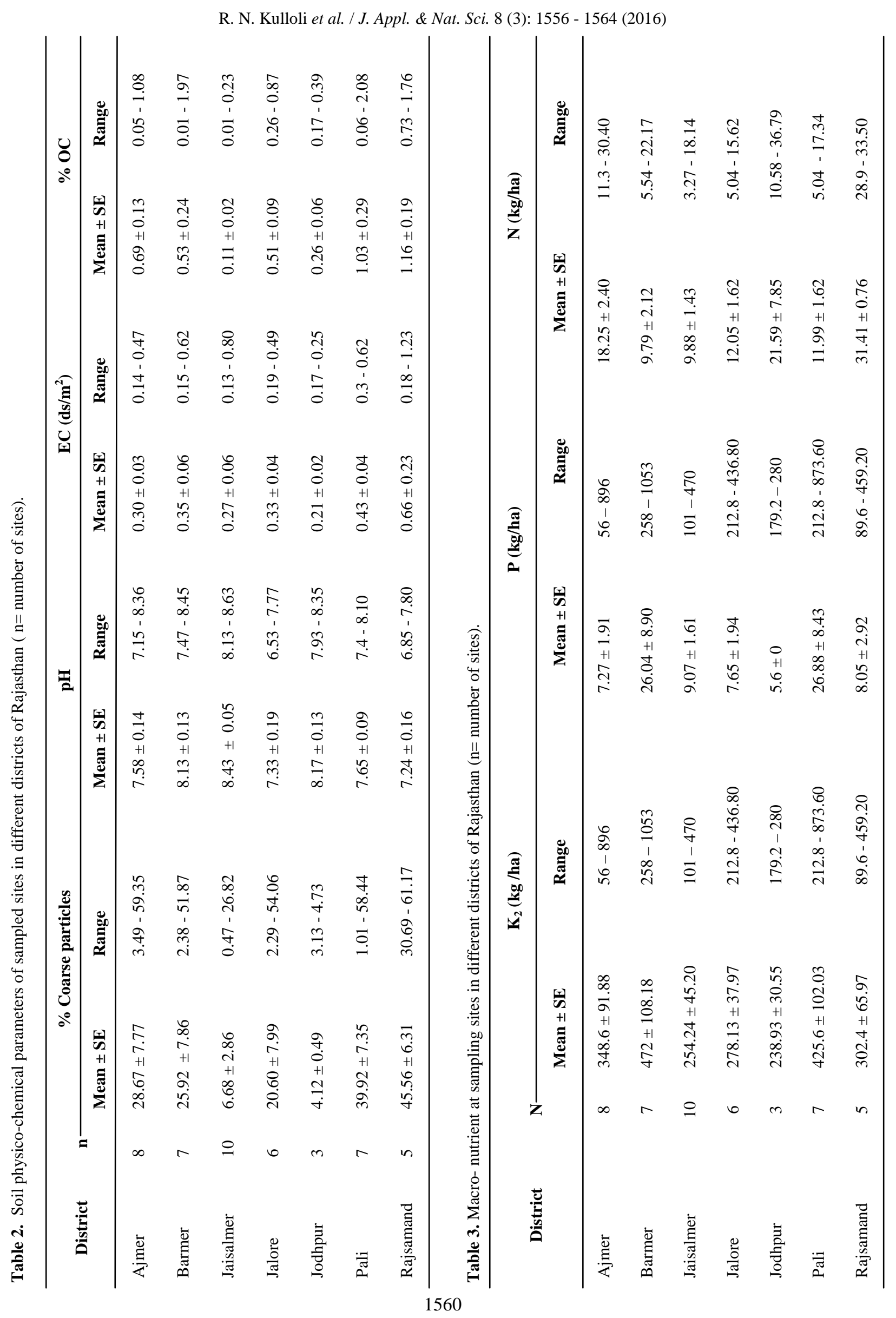


R. N. Kulloli et al. / J. Appl. \& Nat. Sci. 8 (3): 1556 - 1564 (2016)

Table 4. Species diversity parameters of $C$. wightii occurrence sites of study area ( $\mathrm{n}=$ number of sites).

\begin{tabular}{lccccccc}
\hline \multirow{2}{*}{ Districts } & \multirow{2}{*}{$\mathbf{n}$} & \multicolumn{2}{c}{ RIV $\boldsymbol{C}$. wightii } & \multicolumn{2}{c}{ Evenness } & \multicolumn{2}{c}{ Shannon index (H') } \\
\cline { 3 - 7 } & & \multicolumn{1}{c}{ Mean \pm SE } & \multicolumn{1}{c}{ Range } & Mean \pm SE & Range & Mean \pm SE & Range \\
\hline Ajmer & 8 & $9.32 \pm 1.15$ & $5.29-14.66$ & $0.87 \pm 0.024$ & $0.73-0.95$ & $1.67 \pm 0.098$ & $1.23-2.08$ \\
Barmer & 7 & $12.21 \pm 0.96$ & $7.68-14.72$ & $0.88 \pm 0.034$ & $0.75-0.96$ & $1.87 \pm 0.083$ & $1.51-2.14$ \\
Jaisalmer & 10 & $13.25 \pm 2.91$ & $5.71-35.11$ & $0.86 \pm 0.028$ & $0.68-0.97$ & $1.83 \pm 0.069$ & $1.36-2.12$ \\
Jalore & 6 & $17.39 \pm 2.51$ & $10.58-28.52$ & $0.89 \pm 0.036$ & $0.75-0.99$ & $1.85 \pm 0.126$ & $1.38-2.29$ \\
Jodhpur & 3 & $13.12 \pm 2.92$ & $9.89-18.96$ & $0.99 \pm 0.028$ & $0.89-0.99$ & $1.99 \pm 0.288$ & $1.6-2.56$ \\
Pali & 7 & $12.36 \pm 2.51$ & $7.04-23.58$ & $0.91 \pm 0.018$ & $0.82-0.96$ & $1.65 \pm 0.090$ & $1.33-2.0$ \\
Rajsamand & 5 & $16.42 \pm 5.61$ & $5.18-34.87$ & $0.86 \pm 0.053$ & $0.65-0.95$ & $1.66 \pm 0.098$ & $1.37-1.93$ \\
\hline
\end{tabular}

Table 5. Eigen value analysis and other attributes obtained from Principal Component Analysis for Ajmer, Barmer and Jaisalmer districts.

\begin{tabular}{|c|c|c|c|c|c|c|c|c|c|c|c|c|}
\hline \multirow{2}{*}{ Variables } & \multicolumn{4}{|c|}{ Ajmer } & \multicolumn{4}{|c|}{ Barmer } & \multicolumn{4}{|c|}{ Jaisalmer } \\
\hline & F1 & F2 & F3 & F4 & F1 & F2 & F3 & F4 & F1 & F2 & F3 & F4 \\
\hline$\%$ Coarse particles & 0.41 & 0.02 & -0.35 & 0.83 & 0.47 & -0.18 & 0.85 & -0.15 & 0.38 & 0.57 & 0.00 & -0.44 \\
\hline $\mathrm{pH}$ & -0.54 & 0.77 & 0.25 & 0.08 & -0.84 & -0.48 & 0.02 & -0.07 & -0.77 & 0.13 & 0.50 & 0.30 \\
\hline $\mathrm{EC}$ & 0.89 & 0.14 & -0.03 & 0.10 & 0.98 & 0.12 & 0.09 & 0.07 & 0.62 & 0.01 & -0.69 & 0.32 \\
\hline$\% \mathrm{OC}$ & 0.63 & -0.75 & -0.06 & -0.14 & 0.71 & 0.65 & -0.22 & 0.07 & 0.15 & 0.83 & 0.21 & 0.29 \\
\hline $\mathrm{K}_{2} \mathrm{~kg} / \mathrm{ha}$ & 0.89 & 0.15 & 0.38 & 0.01 & 0.87 & -0.33 & 0.21 & 0.22 & 0.96 & -0.05 & -0.21 & -0.07 \\
\hline $\mathrm{P} \mathrm{kg} / \mathrm{ha}$ & 0.74 & 0.24 & 0.30 & -0.04 & 0.97 & 0.12 & -0.08 & 0.09 & 0.51 & -0.13 & 0.43 & -0.48 \\
\hline $\mathrm{N} \mathrm{kg/ha}$ & -0.72 & -0.37 & 0.01 & 0.03 & 0.60 & 0.66 & -0.20 & -0.39 & 0.52 & 0.66 & 0.22 & -0.07 \\
\hline Shannon H & 0.01 & 0.86 & -0.44 & 0.19 & -0.58 & 0.69 & 0.41 & -0.11 & -0.59 & 0.47 & -0.39 & 0.22 \\
\hline Evenness & -0.13 & 0.17 & 0.91 & 0.23 & -0.36 & 0.85 & 0.29 & 0.24 & 0.62 & -0.09 & 0.13 & 0.62 \\
\hline RIV C.wightii & -0.34 & -0.56 & 0.22 & 0.68 & -0.84 & 0.50 & -0.05 & 0.15 & 0.62 & -0.24 & 0.56 & 0.40 \\
\hline Eigenvalue & 3.63 & 2.47 & 1.50 & 1.29 & 5.64 & 2.71 & 1.13 & 0.34 & 3.73 & 1.77 & 1.53 & 1.30 \\
\hline$\%$ Variance & 36.31 & 24.68 & 15.04 & 12.86 & 56.4 & 27.05 & 11.27 & 3.40 & 37.28 & 17.74 & 15.30 & 12.96 \\
\hline$\%$ Cumulative & 36.31 & 60.99 & 76.02 & 88.87 & 56.4 & 83.44 & 94.70 & 98.10 & 37.28 & 55.02 & 70.31 & 83.26 \\
\hline
\end{tabular}

Table 6. Eigen value analysis and other attributes obtained from Principal Component Analysis for Jalore, Pali and Rajsamand districts.

\begin{tabular}{|c|c|c|c|c|c|c|c|c|c|c|c|c|}
\hline \multirow{2}{*}{ Variables } & \multicolumn{4}{|c|}{ Jalore } & \multicolumn{4}{|c|}{ Pali } & \multicolumn{4}{|c|}{ Rajsamand } \\
\hline & F1 & F2 & $\mathbf{F 3}$ & F4 & F1 & F2 & F3 & F4 & F1 & F2 & F3 & F4 \\
\hline$\%$ Coarse particles & 0.16 & 0.32 & -0.93 & -0.04 & -0.60 & 0.53 & -0.47 & 0.34 & 0.33 & -0.54 & 0.72 & 0.29 \\
\hline $\mathrm{pH}$ & 0.65 & 0.74 & 0.17 & 0.00 & -0.71 & 0.63 & 0.12 & -0.01 & -0.75 & 0.47 & 0.41 & 0.24 \\
\hline $\mathrm{EC}$ & 0.27 & -0.80 & 0.44 & 0.29 & 0.73 & 0.18 & -0.54 & -0.13 & 0.92 & 0.33 & -0.19 & -0.09 \\
\hline$\% \mathrm{OC}$ & -0.34 & -0.84 & -0.41 & 0.11 & 0.84 & -0.17 & -0.17 & -0.34 & 0.61 & 0.74 & -0.10 & -0.26 \\
\hline $\mathrm{K}_{2} \mathrm{~kg} / \mathrm{ha}$ & 0.90 & -0.12 & 0.04 & 0.19 & 0.74 & 0.28 & 0.19 & 0.58 & 0.84 & -0.38 & -0.27 & 0.27 \\
\hline $\mathrm{P} \mathrm{kg} / \mathrm{ha}$ & 0.84 & 0.38 & 0.23 & 0.07 & 0.79 & 0.20 & 0.00 & 0.57 & 0.82 & 0.52 & -0.14 & 0.17 \\
\hline $\mathrm{N} \mathrm{kg/ha}$ & -0.13 & 0.33 & -0.11 & 0.92 & 0.57 & -0.09 & 0.79 & -0.02 & 0.02 & 0.70 & -0.12 & 0.70 \\
\hline Shannon H & 0.87 & -0.28 & 0.08 & -0.32 & -0.29 & -0.73 & -0.28 & 0.45 & 0.19 & 0.55 & 0.80 & -0.13 \\
\hline Evenness & -0.87 & 0.40 & 0.10 & -0.15 & -0.78 & -0.16 & 0.44 & 0.19 & 0.84 & 0.02 & 0.52 & -0.15 \\
\hline RIV C.wightii & -0.80 & 0.22 & 0.54 & -0.01 & 0.13 & 0.96 & 0.13 & -0.14 & 0.61 & -0.77 & 0.10 & 0.17 \\
\hline Eigenvalue & 4.31 & 2.53 & 1.63 & 1.11 & 4.30 & 2.35 & 1.50 & 1.17 & 4.39 & 2.97 & 1.76 & 0.89 \\
\hline$\%$ Variance & 43.15 & 25.34 & 16.35 & 11.10 & 43.05 & 23.45 & 14.98 & 11.66 & 43.86 & 29.69 & 17.60 & 8.85 \\
\hline$\%$ Cumulative & 43.14 & 68.47 & 84.81 & 95.90 & 43.05 & 66.5 & 81.48 & 93.14 & 43.85 & 73.53 & 91.13 & 99.98 \\
\hline
\end{tabular}

wightii (-0.79) significantly correlated with component F1 with eigenvalue 4.31 accounting variability $43.14 \%$ while $\mathrm{pH}(0.73)$, EC (-0.79) and percent OC (-0.83) loaded heavily on component F2 with $25.33 \%$ variability in data set (Table 5; Fig.2d). Per cent coarse particles and $\mathrm{N} \mathrm{kg}$ /ha loaded on component F3 and F4 with eigenvalues 1.63 and 1.10 respectively. Among 10 different variables four variables percent $\mathrm{OC}, \mathrm{N} \mathrm{kg} / \mathrm{ha}$, evenness and RIV C.wightii showed negative correlations (Table 5).

Pali district : Based on the significant threshold for variables, six variables loaded on component F1: these variables were $\mathrm{pH}(-0.70), \mathrm{EC}(0.72)$, per cent OC (0.84), K kg/ha (0.74), P kg/ha (0.78) and Evenness (-
0.77). This component F1, accounted for 4.30 of eigenvalue loading and $43.03 \%$ of the variance in data set. Component F2 had two community dynamics properties: Shannon and Weaver (-0.72) and RIV $C$. wightii (0.96), with $23.45 \%$ variation (Table 6; Fig.2e). $\mathrm{N} \mathrm{kg}$ / ha $(0.78)$ was heavily loaded on component F3 with eigenvalue 1.49 accounting for $14.97 \%$ variability. However, components F4 had no variable loaded on it. EC, percent OC, $\mathrm{K} 2 \mathrm{~kg} / \mathrm{ha}, \mathrm{P} \mathrm{kg} / \mathrm{ha}, \mathrm{N} \mathrm{kg} / \mathrm{ha}$ and RIV C. wightii showed positive correlation (Table 6).

Rajsamand district : In the soil and community dynamics data set of Rajsamand district, all variables (10 out of 10) were significant. PH (-0.74), EC (0.92), K 
R. N. Kulloli et al. / J. Appl. \& Nat. Sci. 8 (3): 1556 - 1564 (2016)

Table 7. Trends of significant eigenvalues in PCA axes F1, F2, F3 and F4 with respect to different soil variables in six districts.

\begin{tabular}{|c|c|c|c|c|c|c|c|c|c|}
\hline & & F1 & & F2 & & F3 & & F4 & \\
\hline $\begin{array}{l}\text { Sr } \\
\text { No }\end{array}$ & $\begin{array}{l}\text { Vari- } \\
\text { ables }\end{array}$ & $\begin{array}{l}\text { No of } \\
\text { dis- } \\
\text { tricts }\end{array}$ & Name of districts & $\begin{array}{l}\text { No of } \\
\text { districts }\end{array}$ & $\begin{array}{l}\text { Name of } \\
\text { districts }\end{array}$ & $\begin{array}{l}\text { No of } \\
\text { dis- } \\
\text { tricts }\end{array}$ & $\begin{array}{l}\text { Name of } \\
\text { districts }\end{array}$ & $\begin{array}{l}\text { No of } \\
\text { districts }\end{array}$ & $\begin{array}{l}\text { Name of } \\
\text { districts }\end{array}$ \\
\hline 1 & $\begin{array}{l}\% \\
\text { Coarse } \\
\text { Particles }\end{array}$ & 0 & - & 0 & - & 2 & $\begin{array}{l}\text { Barmer, } \\
\text { Jalore }\end{array}$ & 1 & Ajmer \\
\hline 2 & $\mathrm{pH}$ & 4 & $\begin{array}{l}\text { Barmer, Pali, Jaisalmer, } \\
\text { Rajsamand }\end{array}$ & 2 & $\begin{array}{l}\text { Ajmer, } \\
\text { Jalore }\end{array}$ & 0 & - & 0 & - \\
\hline 3 & $\mathrm{EC}$ & 4 & $\begin{array}{l}\text { Ajmer, Barmer, Pali, } \\
\text { Rajsamand }\end{array}$ & 1 & Jalore & 0 & - & 0 & - \\
\hline 4 & $\% \mathrm{OC}$ & 2 & Barmer, Pali & 4 & $\begin{array}{l}\text { Ajmer, } \\
\text { Jalore, } \\
\text { Jaisalmer, } \\
\text { Ra- } \\
\text { jsamand }\end{array}$ & 0 & - & 0 & - \\
\hline 5 & $\mathrm{~K}_{2} \mathrm{~kg} / \mathrm{ha}$ & 6 & $\begin{array}{l}\text { Ajmer, Jalore, Pali, } \\
\text { Barmer, Jaisalmer, } \\
\text { Rajsamand }\end{array}$ & 0 & J to & 0 & - & 0 & - \\
\hline 6 & $\mathrm{P} \mathrm{kg} / \mathrm{ha}$ & 5 & $\begin{array}{l}\text { Ajmer, Jalore, Pali, } \\
\text { Barmer, Rajsamand }\end{array}$ & 0 & - & 0 & - & 0 & - \\
\hline 7 & $\mathrm{~N} \mathrm{kg/ha}$ & 0 & - & 1 & $\begin{array}{l}\text { Ra- } \\
\text { jsamand }\end{array}$ & 1 & Pali & 2 & $\begin{array}{l}\text { Jalore, } \\
\text { Rajsamand }\end{array}$ \\
\hline 8 & $\begin{array}{l}\text { Shannon } \\
\mathrm{H}\end{array}$ & 1 & Jalore & 2 & $\begin{array}{l}\text { Ajmer, } \\
\text { Pali }\end{array}$ & 1 & $\begin{array}{l}\text { Ra- } \\
\text { jsamand }\end{array}$ & 0 & - \\
\hline 9 & $\begin{array}{l}\text { Even- } \\
\text { ness }\end{array}$ & 3 & Jalore, Pali, Rajsamand & 1 & Barmer & 1 & Ajmer & 0 & - \\
\hline 10 & $\begin{array}{l}\text { RIV } \\
\text { C.wighti } \\
i\end{array}$ & 4 & $\begin{array}{l}\text { Barmer, Pali, Jalore, } \\
\text { Rajsamand }\end{array}$ & 0 & & 0 & & 0 & - \\
\hline
\end{tabular}

$\mathrm{kg} / \mathrm{ha}(0.83), \mathrm{P} \mathrm{kg} / \mathrm{ha}(0.82)$ and Evenness (0.83) were significantly correlated with component $\mathrm{F} 1$ with eigenvalue 4.38 and $43.85 \%$ variability in data set (Table 6). On Component F2 percent OC, N kg/ha (Fig. 2f) and RIV of $C$. wightii were loaded heavily with eigenvalue 2.96 . Percent coarse particles (0.71) and Shannon and Weaver (0.79) were correlated with component F3 with eigenvalue 1.76 accounting $17.60 \%$ variability in data set. Only one variable $\mathrm{N} \mathrm{kg} / \mathrm{ha}$ was loaded on component $\mathrm{F} 4$ with $8.85 \%$ variability. Among 10 variables $\mathrm{pH}$ showed negative correlation (Table 6).

As per PCA, F1 axis explains maximum variability followed by F2, F3 and F4. The trends of significant eigenvalues in these axes (F1-F4) in respect of different soil variables which are detailed in tables 5 and 6 are synthesized in table 7 . Of all the variables, amount of potassium emerged as correlated in maximum number i.e., six districts with F1 axis. This is followed by $\mathrm{F} 1$ axis with respect to $\mathrm{P}(\mathrm{kg} / \mathrm{ha})$ in five districts. Likewise $\mathrm{pH}, \mathrm{EC}$ and RIV of $C$. wightii each in four districts were explained by $\mathrm{F} 1$ axis. The F2 axis in four districts was maximum related to percent OC. In all remaining situations, different variables were explained in one or two districts, either F1 or F2 or F3 or F4 level axis. Thus amount of potassium in soil emerged as most important regulatory factor determining perhaps distribution of $C$. wightii.
PCA is a fact-finding tool that reduces measurement problems, such as bias, and complexity of correlated data, as it extracts only variables that have significant contributions among a set of variables or principal components which account for most of the variance in the observed variables (Johnson and Wichern, 2002; Krefts et al., 2010). A comparison of all parameters (soil and vegetation) in all six districts revealed that potassium emerged as the most dominating regulatory factor as it significantly correlated with F1 components in all the six districts (Table 5) followed by phosphorus in five districts. Surprisingly, Nitrogen was not an important regulatory factor, as it loaded on F3 and F4 axis in soils from only three districts i.e. Pali, Jalore and Rajsamand (Table 6), all receiving rainfall of over $400 \mathrm{~mm}$, while EC and pH have dominantly influencing role in districts in both high and low rainfall areas. Hence, it was thought appropriate to examine the dynamics of $C$. wightii population density vis-à-vis potassium content at different sites.

Since data of soils included all sites (protected and unprotected sites), the dominant soil parameters affecting occurrence of $C$. wightii will have a combined expression of effects of soil and anthropogenic (protection) status. In order to preclude anthropogenic impacts on soil and consequently on plant distribution, soil data of only protected sites were selected for un- 
derstanding this relationship. Further in order to maintain climatic similarities of habitats, only protected sites of Jaisalmer and Barmer were considered. Analysis of soils from habitats of occurrence of $C$. wightii in Jaisalmer and Barmer revealed that potassium is the most important controlling factor. Relating potassium (kg/ha) with RIV of $C$. wightii showed clear trends: decline in potassium content as the RIV decreases confirming that higher amount of $\mathrm{K}$ favors more of $C$. wightii (Fig. 3), as $\mathrm{K}$ is one of the major nutrient elements required and also taken up in large amounts by plants, beside $\mathrm{N}$ and $\mathrm{P}$ (Yogaratnam and Weerasuriyan, 1984). Plants cannot achieve maximum growth and yield without $\mathrm{K}$, nor can the functions that $\mathrm{K}$ performs be fully carried out by another substituting element (Samarappuli et al., 1993). It emerged that K could be therefore a potential regulator in occurrence and dominance of $C$. wightii. This fact was further examined by comparison between potassium quantity and number of $C$. wightii plants per tenth ha. It showed that at higher potassium content the number of $C$. wightii plants per tenth ha was very less. As potassium quantity declines moderately then number of $C$. wightii plants per tenth ha increases (Fig. 4). Examing graphically, it emerged that 200 to $300 \mathrm{~kg} / \mathrm{ha}$ potassium quantity seemed to be favouring maximum number of C. wightii plants per tenth ha. The similar trend was found in case of height and canopy of $C$. wightii plant. As quantity of potassium declined across sites, vigor of C. wightii plant in terms of height and canopy increases (Figs. 5 and 6), which confirmed results of Samarappuli et al. (1993) and Uddin et al. (2013). Samarappuli et al. (1993) had reported that increasing the level of applied K to twice the original would tend to retard the rate of growth of Hevea brasilensis in Sri Lanka. Though $H$. brasilensis and $C$. wightii occur in contrasting bioclimates, both have the same quality of producing secondary metabolite i.e. latex in $H$. brasilensis and oleo gum resin in $C$. wightii and hence their response to potassium was quite similar. Potassium controls the distribution of vegetation types in Yazd province, Iran. PCA and CCA results showed that potassium indicates $A$. sieberi type vegetation (Chahouki et al., 2008).

In fact amongst all variables of environment studied in the present work, $\mathrm{K}$ content has a most dominating regulatory role. Potassium plays a vital role in plant growth and metabolism, although it is not a constituent of any known plant components (Read et al., 2006). As an enzyme activator, potassium has been implicated in over 60 enzymatic reactions, which are involved in many processes in the plant such as photosynthesis, respiration, carbohydrate metabolism, translocation and protein synthesis (Dong et al., 2004; Pettigrew, 2008). Potassium also plays an important role in the maintenance of osmotic potential and water uptake (Oosterhuis, 2001).

In arid and semiarid regions, the relation between species distribution and potassium gradient has been re- ported by Chahouki et al. (2008). In the present study also, results of PCA showed that $C$. wightii has strong relationship with potassium. Distribution of Artemisia sieberi in Egypt is controlled by potassium (Jafari et al., 2004). Apart from induction of physiological responses, the variations in mineral nutrient availability often evoke some alterations in root architecture. In barley and many other plants, low potassium supply resulted in a reduction of total lateral root length (Drew, 1975). The observed pattern of morphological responses may also be associated with the high mobility of K in the plant body (Hodge, 2004). Similar to barley (Drew, 1975), potassium deficiencies arrested lateral root development in Arabidopsis (Shin and Schachtman, 2004; Armengaud et al., 2004).

Physiologically, increased levels of ethylene may be responsible for the inhibition of lateral root development observed in the $\mathrm{K}+$ starved plants. Reduced potassium availability triggered agravitropic root growth in the plants. This reaction to the low $\mathrm{K}+$ status may be important for mineral acquisition in soils where $\mathrm{K}+$ distribution is heterogeneous (Ashley et al., 2006). If development of lateral roots is inhibited by $\mathrm{K}+$ deficiency, then $C$. wightii being a shrub which would only be producing a lot of lateral roots is expected to perform poorly in $\mathrm{K}$ deficient soil because of lack/paucity of lateral roots. If this is so, then the height and canopy should be less in $\mathrm{K}+$ deficient soils. However our results are different: canopy cover and height of $C$. wightii are lesser at both very low and very high $\mathrm{K}+$ contents (Fig. 6). This shows that mid ranges of $\mathrm{K}+$ seems to have favourable impact on plant vigour. While this would need an experimental confirmation by designing growth experiment in a separate study which is out of scope of the present work, yet suffice it to say that while selecting sites for in-situ conservation of $C$. wightii, care should be taken to select such sites which have $\mathrm{K}+$ in the range of $200-300 \mathrm{~kg} / \mathrm{ha}$ i.e., neither deficient nor very high as both situations seemingly disfavor its growth development, establishment and consequently occurrence and distribution pattern.

\section{Conclusion}

The study concluded that principal component analysis (PCA) effectively brought correlation of different parameters of soil with its occurrence. Of these, the mid ranges of potassium $(200-300 \mathrm{~kg} / \mathrm{ha})$ emerged as favourable to have better density and health of $C$. wightii: This is the first report on regulatory role of potassium on distribution and occurrence of $C$. wightii.

\section{ACKNOWLEDGEMENTS}

We are grateful to Director, CAZRI for providing necessary facilities for this work. The authors thank National Medicinal Plant Board, Govt. of India, New Delhi for financial support (Project No. GO/GUJ-10/2008). 


\section{REFERENCES}

Allen, S.E., Grimshaw, H.M., Parkinson, J.A., Quarmby, C. and Roberts, J.D. (1976). Chemical analysis In: Methods in Plant Ecolgy (ed.) S.B. Chapman. Blackwell Scientific Publications, Oxford, pp. 536.

Armengaud, P., Breitling, R. and Amtmann, A. (2004). The potassium dependent transcriptome of Arabidopsis reveals a prominent role of jasmonic acid in nutrient signaling. Plant Physiology, 136: 2556-2576.

Ashley, M. K., Grant, M. and Grabov, A. (2006). Plant responses to potassium deficiencies: a role for potassium transport proteins. Journal of Experimental Botany, 57 (2): 425-436.

Chahouki Zare, M. A., Azarnivand, H., Jafari, M. and Shafizadeh, M. (2008). Effect of soil characteristics on distribution of vegetation types in poshtkouh rangelands of Yazd province (Iran). Journal of Environmental Research and Development, 2 (4): 840-848.

Chauhan, A. (2004). Ecological studies on some arid medicinal plants. PhD. Thesis submitted to Jai Narain Vyas University, Jodhpur. 297 p.

Dong, H., Tang, W., Li, Z. and Zhang, D. (2004). Onpotassium deficiency in cotton-disorder, cause and tissue diagnosis. Agriculturae Conspectus Scientificus, 69 (23): 77-85.

Drew, M.C. (1975). Comparison of the effects of a localized supply of phosphate, nitrate, ammonium and potassium on the growth of the seminal root system and the shoot in barley. New Phytologist, 75: 479-490.

Engler, R., Guisan, A. and MigClim. (2009). Predicting plant distribution and dispersal in a changing climate. Diversity and Distributions, 15: 590-601.

Graham, C.H., Smith, T.B. and Languy, M. (2005). Current and historical factors influencing patterns of species richness and turnover of birds in the Gulf of Guinea Highlands. Journal of Biogeography, 32: 1371-1384.

Hodge, A. (2004). The plastic plant: root responses to heterogeneous supplies of nutrients. New Phytologist, 162: 9-24.

Iwara, A. I., Ogundele, F. O., Ibor. U.W. and Deekor, T. N. (2011). Multivariate analysis of soil-vegetation interrelationships in a South-Southern secondary forest of Nigeria. International Journal of Biology, 3 (3): 73-82.

Jackson, M. L. (1973). Soil chemical analysis. Prentis, Hall of India Private Limited, New Delhi, 498 p.

Jafari, M., M.A. Zare Chahouki, A. Tavili, Azarnivand H. and Gh. Zahedi Amiri, (2004). Effective environmental factors in the distribution of vegetation types in Poshtkouh rangelands of Yazd Province (Iran). Journal of Arid Environments, 56: 627-641.

Johnson, R. A. and Wichern, D. E. (2002). Applied Multivariate Statistical Analysis, Prentice Hall, NJ, USA.

Krefts, A. C., Schwarz N. G. and Krumah B. N. (2010). "Principal component analysis of socioeconomic factors and their association with malaria in children from the Ashanti Region, Ghana," Malaria Journal Vol 9, no.1
Kumar, S. (1996). Trends in structural compositional attributes of dune interdune vegetation and their edaphic relations in the Indian Desert. Vegetatio, 124: 73-93.

Kumar, S. and Mathur, M. (2014). Impact of invasion by Prosopis juliflora on plant communities in arid grazing lands. Tropical Ecology, 55(1): 33-46.

Kumar, S. and Purohit, C. S. (2015). Conservation of Threatened Desert Plants.Scientific Publishers, India. 148p.

Kumar, S. and Shankar, V. (1982). Medicinal plants of the Indian desert: Commiphora wightii (Arnott) Band. Journal of Arid Environments, 5: 1-11.

Kumar, S. and Shankar, V. (1988). Vegetation ecology of Bandi catchment in the upper Luni Basin western Rajasthan. Tropical Ecology, 28: 246-258.

Lal, H. (2013). Germplasm collection and propagation of $C$. wightii (Arnt.) Bhandari, an endangered medicinal plant of the Indian Thar Desert. Unpublished PhD Thesis, Jai Narain Vyas University, Jodhpur.

Ludwig, J. A. and Reynolds, J.F. (1988). Statistical Ecology: A primer on methods and computing. John Wiley and Sons, NY, USA.

Mathur, M. (2012). Variations in phytosterol composition in Corchorus depressus and their relation with bottom-up, top-down and plant metabolites. Journal of Natural Products, 5: 179-187.

Oosterhuis, D. (2001). Physiology and nutrition of high yielding cotton in the USA. Informac, óes Agronômicas Piracicaba, 95: 18-24.

Pettigrew, W.T. (2008). Potassium influences on yield and quality production for maize, wheat, soybean and cotton. Physiologia Plantarum, 133: 670-681.

Read, J.J., Reddy, K.R. and Jenkins, J.N. (2006). Yield and fiber quality of Upland cotton as influenced by nitrogen and potassium nutrition. European Journal of Agronomy, 24: 282-290.

Samarappuli, L., Yogratnam, N., Karunadasa, P., Mirasena, U. and Hettiarachchi, R. (1993). Role of potassium om growth and water relations of rubber plants. Journal of Rubber Research Institute, Sri Lanka, 73: 37-57

Shin, R. and Schachtman, D.P. (2004). Hydrogen peroxide mediates plant root cell response to nutrient deprivation. Proceedings of the National Academy of Sciences, USA. 101: 8827-8832.

Singh, G., Singh, K., Mishra, D. and Shukla, S. (2012). Vegetation diversit and role of Leptadinia pyrotechnica in biomass utilization and carbon storage in Arid Zone of India. Arid Ecosystem, 2(4): 264-272.

Subbiah, B.V. and Asija, C.L. (1965). A rapid procedure for the estimation of available nitrogen in soils. Current Science, 25: 259-260.

Uddin, S., Sarkar, M.A.R. and Rahman, M.M. (2013). Effect of nitrogen and potassium on yield of dry direct seeded rice cv. NERICA 1 in aus season. International Journal of Agronomy and Plant Production, 4 (1): 69-75.

Yogaratnam, N. and Weerasuriya S. M. (1984). Recent developments in the nutrition of Hevea in Sri Lanka. Proceedings of Internatinal Rubber Conference ,Sri Lanka, 1: 207 - 247 